\title{
THE CONSIDERATION AND PURPOSE OF BORROWING: AN EMPIRICAL EVIDENCE FROM INDONESIA LISTED COMPANIES
}

\author{
Ventje Ilat and Winston Pontoh \\ Faculty of Economic and Business, Sam Ratulangi University, Manado, Indonesia
}

Received 2014-02-12; Revised 2014-02-15; Accepted 2014-05-02

\begin{abstract}
Debt often graced in most of capital structure of companies, particularly in financial statement and became issues in context of trade off theory and pecking order theory in most studies. Debt usually related with profit matter, because it is always want to be achieved by every companies. It started when companies own equity is insufficient to create investment in company's assets for making profit, then it make debt is one alternative fund for financing investments aimed at achieving the desired profit. The objective of this study is to give answers as empirical evidence for the questions about why companies need debt and what is the relevance capital structure theory to explain this behavioral tendency in these period of observation. Conducting path analysis with trimming model as method of analysis, the results shows that, degree of operating leverage is negatively significant to debt equity ratio and debt equity ratio is negatively significant to return on equity. The implication of this findings shows the application of pecking order theory, because most of companies depend their funding from internal, which is make them have more stable cash flow and beside that, the consideration of business risk is very important so they keep the capital structure in optimum debt that make them have low probability of bankruptcy.
\end{abstract}

Keywords: Capital Structure, Profitability, Debt Equity Ratio, Return on Equity, Growth, Size, Tangibility

\section{INTRODUCTION}

There was an interested statement from Myers (1984), "How do firms choose their capital structures?" And the answer is, "We don't know." It was always became a question, why most of companies need debt for financing their operations? Because debt often graced in most of capital structure of companies, particularly in financial statement. Issues of debt emergence always been in debate in context of trade off theory and pecking order theory in most studies. Is debt a coincidence factor? Is debt an important factor that needed by companies for financing its investments in order to achieve profit? What is the main reason for emergence of debt to each company?

We were noticed statement from Myers (2001) where, there were several useful conditional theories.
The trade off theory says that firms seek debt levels that balance the tax advantages of additional debt against the costs of possible financial distress. The tradeoff theory predicts moderate borrowing by taxpaying firms. The pecking order theory says that the firm will borrow, rather than issuing equity, when internal cash flow is not sufficient to fund capital expenditures. Thus the amount of debt will reflect the firm's cumulative need for external funds. The free cash flow theory says that dangerously high debt levels will increase value, despite the threat of financial distress, when a firm's operating cash flow significantly exceeds its profitable investment opportunities. The free cash flow theory is designed for mature firms that are prone to overinvest. Moreover, in general, industry debt ratios are low or negative when profitability and business risk are high.

Corresponding Author: Ventje Ilat, Faculty of Economic and Business, Sam Ratulangi University, Manado, Indonesia 
Intangible assets are also associated with low debt ratios. High profits mean low debt and vice versa. But if managers can exploit valuable interest tax shields, as the tradeoff theory predicts, then the result is opposite relationship. High profitability means that the firm has more taxable income to shield and that the firm can service more debt without risking financial distress.

Based on these theories, we strongly believe that, for companies in developing countries, profit represent primary factor which always wish to be achieved by every companies and that made companies must empowered all of its resources optimally, such as current assets, fixed assets and other assets. The problem arise when companies equity is insufficient to create company's assets, then it make debt as one alternative fund for financing investments aimed at achieving the desired profit. When a policy decided to acquire the debt, then another problem arise because lender would review the ability of companies for make profit, so the ability to make a profit or profitability is a key factor for the companies to obtain debt. But, when the debt were obtained, then the capital structure will change and as the consequences, the company's profitability reducing as the impact of interest expense and also, companies more closely to its risk of bankruptcy. So, consideration for profitability in capital structure is very important for every companies, because Myers (1984) stated, an unprofitable firm in the same industry will end up with a relatively high debt ratio.

Then, we reviewed the main points of (Myers, 2001; 1977; Kale et al., 1991; Leland and Pyle, 1977) about relationship between debt, profitability and business risk. The other works, Myers (1984), added these relationship with growth and tangibility, while Mohamad and Abdullah (2012) and also Chen (2004) added with size. We noticed of some works about relationship debt, profitability and growth (San and Heng, 2011), relationship of debt and profitability (Nadaraja et al., 2011; Ahmadinia et al., 2012; Shubita and Alsawalhah, 2012; Ching et al., 2011; Frank and Goyal, 2003), relationship of debt, growth and size (Homaifar et al., 1994), relationship of debt, size and tangibility (Shamshur, 2010), relationship of debt, growth, size and tangibility (Shah and Khan, 2007; Lim et al., 2012), relationship of profitability, growth and business risk (Lev, 1974), relationship of debt and growth (Sunder and Myers, 1999; Baker and Wurgler, 2002) and the relationship of debt, size, bankruptcy risk and tangibility (Marsh, 1982).
Then, we were identified that, most companies in Indonesia which are examines in this study, have debt over their equities, means the debt ratio is more than 1 . In period of 2009 till 2011, there are some phenomenon showed by these companies, where their debt ratio (debt to equity ratio) is tendency to decrease and profitability (return on equity) is tendency to increase, while growth (change percentage in total assets) and size (natural logarithm of total asset) of these companies have tendency to increase, but tangibility shifting closely in constant and also, the business risk (degree of operating leverage) is high or below than 1 .

Furthermore, we linking these variables to analyze the tendency to behave of these variables and to give an appropriate explanation about this phenomenon. Our objective of this study is to give answers as empirical evidence for the questions about why companies need debt and what is the relevance capital structure theory to explain this behavioral tendency in these period of observation, because we suspect, in developing countries such as Indonesia, this is about survival for sustainability matter of these companies, where bankruptcy is still the main consideration of companies in Indonesia, since financing decision is related with business risk. Our contribution by this study is not taking style pros and cons in significant or insignificant of others prior research, but through of our study we want to add another reference for next research in the same area to understand what is the reasonable debt philosophy, with explanation as neutral as possible, because we believe each period of observation in every research has its own phenomenon and has its own relevance theories to explain this phenomenon, since we keep up with Myers (2001) that, there is no universal theory of the debt equity choice and no reason to expect one.

\section{LITERATURES REVIEW}

First of all, we agreed with Myers (2001) that, there is no universal theory of the debt equity choice and no reason to expect one. Myers (2001), concluded in his research, first, firms prefer internal to external finance. (Information asymmetries are assumed relevant only for external financing). Second, dividends are "sticky," so that dividend cuts are not used to finance capital expenditure and so that changes in cash requirements are not soaked up in short-run dividend changes. In other words, changes in net cash show up as changes in external financing. Third, if external funds are required 
for capital investment, firms will issue the safest security first, that is, debt before equity. If internally generated cash flow exceeds capital investment, the surplus is used to pay down debt rather than repurchasing and retiring equity." As the requirement for external financing increases, the firm will work down the pecking order, from safe to riskier debt, perhaps to convertible securities or preferred stock and finally to equity as a last resort. Fourth, each firm's debt ratio therefore reflects its cumulative requirement for external financing.

Furthermore, Mohamad and Abdullah (2012), stated, trade off theory implies that leverage has positive relationship with profitability as contrary to the pecking order theory. Trade off theory considers the cost of bankruptcy associated with the debt financing and the benefit of tax advantage. Trade-off theory asserts that a company may set a target debt to company value and gradually moves towards it. According to this theory, the increase in debt level will increase the cost of bankruptcy, financial distress and agency, hence decrease the value of the company. Thus, a company needs to find equilibrium where the level of debt would be able to offset its costs (such as tax advantages of the debts) with the costs of possible financial distress. According to this theory, companies with high growth have more risk and higher financial distress costs, thus growth have an inverse relationship with debt level. However, if a company has higher level of fixed assets to serve as collateral for debt financing, it will give easier access for the company to obtain debt, thus give a positive relationship between asset tangibility and debt level.

Nadaraja et al. (2011) stated, pecking order theory suggest that management would prefer equity financing in favor of debt financing in view of information asymmetry condition and benefit of reduced transactions costs. Based on this theory, highly profitable firms will tend to use internal funding, whereas firms with low profitability tend to use external financing. In the context of internal finance, the theory indicated internal fund such as retained earnings is preferred and as for external financing, debt is chosen over equity. Also, if a firm use of external financing would indicate that the firm is not profitable, its stock price may be adversely affected. This related to information asymmetric where the managers usually have more information on the firm. Therefore, they would issue new shares when it is believed that the stock price is fairly or overly priced only. Ahmadinia et al. (2012), stated, the pecking order theory does not take an optimal capital structure as a starting point, but instead asserts that firms prefer to use internal finance (as retained earnings or excess liquid assets) over external finance. If internal funds are not enough to finance investment opportunities, firms may or may not acquire external financing and if they do, they will choose among the different external finance sources in such a way as to minimize additional costs of asymmetric information. In order to minimize external cost of financing, firms prefer to use debt leverage at first, then issuance of preferred stock and finally issuance of common stock. Ahmadinia et al. (2012), conclude there is a close relationship between profitability and capital structure. Homaifar et al. (1994) found, firm size and future growth opportunities appear to be important determinants of the capital structure. Shamshur (2010), found that size and tangibility have a significant relationship with debt to equity ratio. Supported by Shah and Khan (2007), found that tangibility and growth have significant relationship with leverage, but insignificant for its size. While in other side, Lim et al. (2012), found that size, growth and tangibility had not significant relationship with debt asset ratio.

Myers (1977), stated, factors should be associated with heavy debt financing are capital intensity, high operating leverage and profitability. Supported by Kale et al. (1991) that, business risk is one of the primary determinants of a firm's capital structure, because existence of debt in the capital structure increases the probability of bankruptcy and firms with more variable cash flows, that is, higher business risk, have a higher probability of bankruptcy for a given level of debt. Bodie et al. (2009), stated that firms with greater amounts of variable as opposed to fixed costs will be less sensitive to business conditions. This is because in economic downturns, these firms can reduce costs as output falls in response to falling sales. Profits for firms with high fixed costs will swing more widely with sales because costs do not move to offset revenue variability. Firms with high fixed costs are said to have high operating leverage, because small swings in business conditions can have large impacts on profitability. Furthermore, degree of operating leverage greater than 1 indicates some operating leverage, means, if operating leverage is change then profit will change in the same 
direction, means, degree of operating leverage increases with a firm's exposure to fixed costs. Measurement for business risk supported by Chowdhury and Chowdhury (2010) that, business risk is represented by operating leverage and according to Lev (1974), that, in general, the higher the operating leverage, the higher the earnings volatility with respect to demand fluctuations related with growth and profitability.

San and Heng (2011), stated that capital structure is essential on how a firm finances its overall operations and growth by using different sources of funds. They found that no relationship between debt asset or debt equity ratio to return on asset. This findings supported by Shubita and Alsawalhah (2012), that there is significantly negative regression coefficient for total debt implies that an increase in the debt position is associated with a decrease in profitability: Thus, the higher the debt, the lower the profitability. Ahmad et al. (2012), found that only short term debt and total debt have significant relationship with ROA while ROE has significant on each of debt level. This findings has similiar results with Ching et al. (2011), found that debt asset ratio effected to return on assets and supported by Mohamad and Abdullah (2012), found that debt equity ratio negatively related with return on equity but negatively insignificant association with return on asset. This indicates that any increase in ROE can be explained by a reduction in debt equity ratio but not for ROA. The regression results for debt asset ratio having negative association with ROE and ROA. This implies that the increase or decrease of debt level will significantly affect the firm's performance, which means that reducing the debt level will significantly increase ROE and ROA.

Leland and Pyle (1977) stated, firms with riskier returns will have lower debt levels even when there are no bankruptcy costs. This might be because, according to Baker and Wurgler (2002), the idea is that firms with substantial growth and investment opportunities have the most to lose when over-hanging debt prevents new capital from being raised or leads to an inefficient bankruptcy negotiation during which some investment opportunities are forever lost. According to Myers (1984), unusually profitable firm in an industry generating relatively slow growth. That firm will end up with an unusually low debt ratio compared to its industry's average and it won't do much of anything about it. It won't go out of its way to issue debt and retire equity to achieve a more normal debt ratio. An unprofitable firm in the same industry will end up with a relatively high debt ratio. If it is high enough to create significant costs of financial distress, the firm may rebalance its capital structure by issuing equity. Risky firms ought to borrow less, other things equal. Here "risk" would be defined as the variance rate of the market value of the firm's assets. The higher the variance rate, the greater the probability of default on any given package of debt claims. Since costs of financial distress are caused by threatened or actual default, safe firms ought to be able to borrow more before expected costs of financial distress offset the tax advantages of borrowing. Firms holding tangible assets-in-place having active second-hand markets will borrow less than firms holding specialized, intangible assets or valuable growth opportunities. The expected cost of financial distress depends not just on the probability of trouble, but the value lost if trouble comes. Specialized, intangible assets or growth opportunities are more likely to lose value in financial distress. Borrowing against intangibles and growth opportunities. Firms holding valuable intangible assets or growth opportunities tend to borrow less than firms holding mostly tangible assets. There is plenty of indirect evidence indicating that the level of borrowing is determined not just by the value and risk of the firm's assets, but also by the type of assets it holds. Firms with high operating profitability and therefore plenty of unshielded income, may also have valuable intangible assets and growth opportunities. Another statement Sunder and Myers (1999) said that, growth firms that would be more likely to seek external equity financing at low debt ratios.

Frank and Goyal (2003) said, from the point of view of an outside investor, equity is strictly riskier than debt. Both have an adverse selection risk premium, but that premium is large on equity. Therefore, an outside investor will demand a higher rate of return on equity than on debt. From the perspective of those inside the firm, retained earnings are a better source of funds than is debt and debt is a better deal than equity financing. Accordingly, the firm will fund all projects using retained earnings if possible. If there is an inadequate amount of retained earnings, then debt financing will be used. Thus, for a firm in normal operations, equity will not be used and the financing deficit will match the net debt issues. At the typical firm, internal cash flow does lead to some reduction in debt issues, but the magnitude of the effect is surprisingly small once one includes the behavior of firms that do not have complete trading 
records. There is a large literature showing a negative relation between leverage and profitability. However, as noted earlier, if internal cash flow measures future growth opportunities, then the tradeoff theory also predicts the observed negative relation on cash flows.

\section{HYPOTHESIS AND MODELS}

We summarized that, there were relationship between debt and profitability (Ahmad et al., 2012; Ahmadinia et al., 2012; Shubita and Alsawalhah, 2012; Ching et al., 2011; Nadaraja et al., 2011; Frank and Goyal, 2003) and those variables also had relationship with business risk (Myers 2001; Kale et al., 1991; Marsh, 1982; Myers, 1977; Leland and Pyle, 1977; Lev, 1974), growth (Lim et al., 2012; San and Heng, 2011; Shah and Khan, 2007; Baker and Wurgler, 2002; Sunder and Myers, 1999; Homaifar et al., 1994; Myers, 1984; Lev, 1974), tangibility (Lim et al., 2012; Shamshur, 2010; Shah and Khan, 2007; Myers, 1984; Marsh, 1982) and size (Lim et al., 2012; Mohamad and Abdullah, 2012; Shamshur, 2010; Shah and Khan, 2007; Chen, 2004; Homaifar et al., 1994; Marsh, 1982). Then we developed the hypothesis for this study as follows:

H1: Growth, size, tangibility, business risk and debt has direct relationship with profitability

$\mathrm{H} 2$ : Growth, size, tangibility and business risk, has indirect relationship with profitability, mediated by debt

Based on hypothesis we are describing the framework for this study in Fig. 1.

For testing of hypothesis, the equations for model has been developed as follows:

$$
\begin{aligned}
\text { DER }= & \alpha+\beta \text { GROWTH }+\beta \text { SIZE }+\beta \text { TANGIB }+\beta \text { DOL } \\
& +\epsilon \\
\text { ROE }= & \alpha+\beta \text { GROWTH }+\beta \text { SIZE }+\beta \text { TANGIB }+\beta \text { DOL } \\
& +\beta \text { DER }+C
\end{aligned}
$$

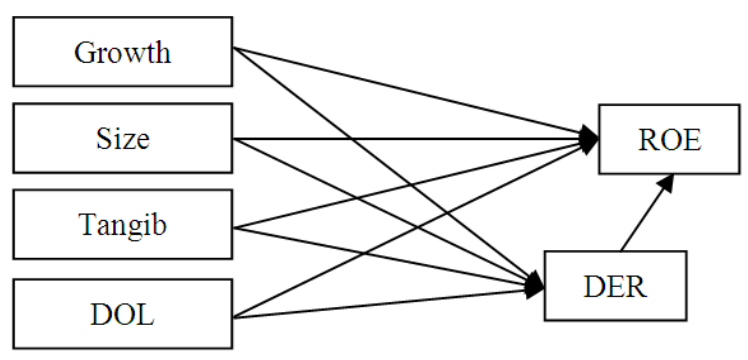

Fig. 1. Framework of study

\section{METHOD OF ANALYSIS}

\subsection{Measurement of Variables}

Method of analysis of this research is using path analysis with trimming model and variables which used in this research described as follows:

As proposed by Ahmadinia et al. (2012), capital structure is usually measured by the following ratios: Ratio of debt to total asset, the equity ratio to total asset, a debt ratio to the equity and equity ratio to debt. Profitability is defined as the ability of a firm to gain profit. Profitability is the result of all financial plans and decisions. The ratio of profit to sell, Return On Asset (ROA) and Return On Equity (ROE) are generally applied to measure profitability. Based on this, we determine variables as indicators of capital structure is Debt Equity Ratio (DER), which calculated by total debt divided by total equity. Also, variables as indicators of profitability is Return On Equity (ROE), which calculated by net profit divided by total equity.

Variables as indicators of determinant of capital structure:

- Growth (GROWTH), calculated by percentage change in total assets. This variable following measurement of (Titman and Wessels, 1988; Hovakimian et al., 2001) and also Hymer and Pashigian (1962)

- $\quad$ Size (SIZE), calculated by log natural of total assets. This variable following measurement of (Hansen and Wernerfelt, 1989; Hoskisson et al., 1994; Zhou, 2000; Dittmar, 2000; Hovakimian et al., 2001; Cheng, 2005; Khrawish and Khraiwesh, 2010)

- Tangibility (TANGIB), calculated by fixed assets divided by total assets. We summarized this variable from measurement of (Gompers, 1995; Rajan and Zingales, 1995; Hovakimian et al., 2004; Baker and Wurgler, 2002; Molina, 2005; Khrawish and Khraiwesh, 2010). We were excluded intangible assets and inventory from measurement of Titman and Wessels (1988) by reasons, intangible assets has unpredicted usage and inventory has short term turnover, these characteristics are different from fixed assets

- We were following suggestions by Kale et al. (1991), about variance cash flow for proxy of business risk, could not be assumed as constant considered the effect of depreciation, tax and interests. So we determine, business risk represented by Degree of Operating Leverage (DOL) is 
calculated by percentage change in Earnings Before Interest and Tax (EBIT) divided by percentage change in sales revenue, because we think this measurement is more realistic in present conditions. The variable measurement based on and (Bodie et al., 2009; Myers, 1977; Chowdhury and Chowdhury, 2010; Lev, 1974)

\subsection{Research Data}

This research based on data from Indonesia Stock Exchange for period of 2009 to 2011, where 247 companies was chosen for samples in sectors as in Table 1.

\section{RESULTS OF ANALYSIS}

Results of regression was conducted and obtained standardized coefficient for the path analysis. The first statistics output by SPSS shows as in Table 2.

The second statistics output by SPSS shows Table 3 .

The first result of regressions shows, growth, size and tangibility are insignificant relationship to debt equity ratio, while degree of operating leverage is negatively significant. The second result of regression shows, growth, size, tangibility and degree of operating leverage are insignificant to return on equity, while debt equity ratio is negatively significant. The mean value for each variables, are summarized in Table 4.

We summarized the results of regressions for standardized coefficients in Table 5.

We applied trimming model for path analysis and the result shows Fig. 2.

Table 1. Research data

\begin{tabular}{ll}
\hline Sectors & Amount \\
\hline Agriculture & 12 \\
Mining & 21 \\
Basic Industry and chemicals & 49 \\
miscellaneous industry (automotive, & 38 \\
components, textile, garments, & \\
footwear, cable, electronics) & \\
Consumer goods industry & 29 \\
infrastructure, utilities and transportation & 23 \\
trade, services and investment & 75 \\
\hline
\end{tabular}

Table 2. Standardized coefficients of first model

\begin{tabular}{lll}
\hline Model & Standardized coefficients & Significance \\
\hline Growth & 0.033 & 0.361 \\
Size & 0.061 & 0.100 \\
Tangibility & -0.014 & 0.696 \\
DOL & -0.093 & 0.011 \\
\hline
\end{tabular}

Dependent variable: Debt to equity ratio

\section{DISCUSSION}

From results of analysis, there are two implications of this research, first, if degree of operating leverage increase, then debt equity ratio would decrease. This is means that business risk for in this case represented by degree of operating leverage is very important factor for determinant capital structure related to bankruptcy and its impact to wealth of shareholders.

Table 3. Standardized coefficients of second model

\begin{tabular}{lll}
\hline Model & Standardized coefficients & Significance \\
\hline DER & -0.522 & 0.000 \\
Growth & 0.013 & 0.673 \\
Size & 0.033 & 0.294 \\
Tangibility & 0.059 & 0.064 \\
DOL & -0.030 & 0.343 \\
\hline Dep
\end{tabular}

Dependent variable: Return on equity

Table 4. Mean value of variables

\begin{tabular}{llllll}
\hline DER & Growth & Size & Tangib & DOL & ROE \\
\hline 1.54 & 0.37 & 13.85 & 0.36 & -14.60 & 0.13 \\
\hline
\end{tabular}

Table 5. Path analysis

\begin{tabular}{lccc}
\hline Variables & $\begin{array}{l}\text { Direct } \\
\text { effect }\end{array}$ & $\begin{array}{l}\text { Indirect } \\
\text { effect }\end{array}$ & $\begin{array}{l}\text { Total } \\
\text { effect }\end{array}$ \\
\hline DER & -0.522 & - & -0.522 \\
Growth & 0.013 & -0.017 & -0.004 \\
Size & 0.033 & -0.032 & 0.001 \\
Tangibility & 0.059 & 0.007 & 0.066 \\
DOL & -0.030 & 0.049 & 0.019 \\
\hline
\end{tabular}
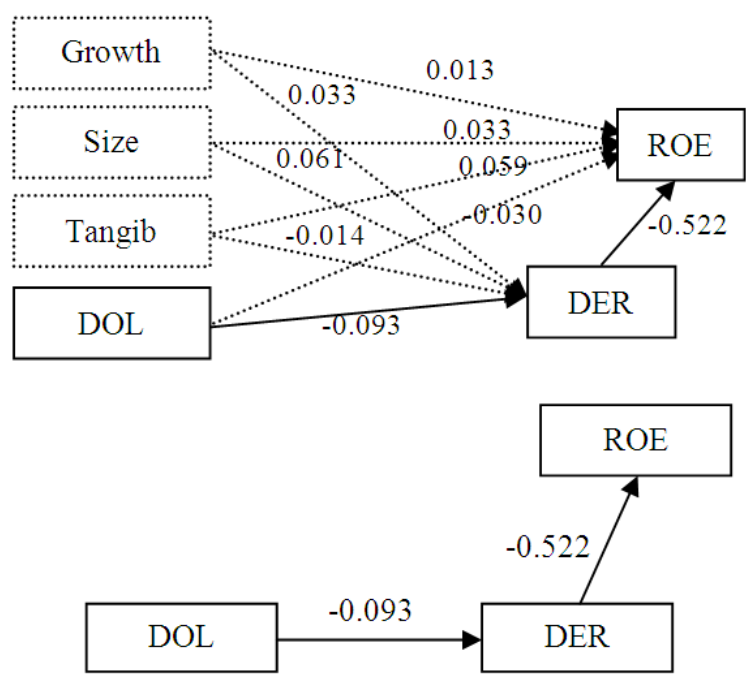

Fig. 2. Path analysis with trimming model 
This findings are consistent with (Myers, 1977; Kale et al., 1991; Nadaraja et al., 2011; Bodie et al., 2009). Second, if debt equity ratio increase, then return on equity would decrease. It means, although companies obtain large amount of debt but it cannot cross the line of the optimum debt or the profit will be decline. This findings are consistent with (Mohamad and Abdullah, 2012; Shubita and Alsawalhah, 2012; Ahmad et al., 2012; Ahmadinia et al. (2012).

There are few points noticed from side of growth, size and tangibility as representation for assets specially for fixed assets because it is the most important factors for companies to create earnings, but still it is not significant to return on equity. Based on the mean values , the characteristics of the companies included in this research sample is a companies that has a profit, has a fairly low fixed costs based on degree of operating leverage, has a fairly size of assets, having a low asset growth, have low fixed assets and has high enough debt above the capital itself. Based on these characteristics, it can be said that the total assets in these companies largely financed by debt. However, mostly of debt was not allocated for investment in fixed assets and it shows from a comparison of fixed assets over total assets (tangibility) and growth in fixed assets, also, the value of tangibility shows a negative relationship between debt and fixed asset investment. With the investment in fixed assets is not oriented, then causes these companies have lower fixed costs refers to depreciation expense and interest expense of debt, so if the value based on the size, we were assumed that the utilization of the allocation of debt is more allocated to the investment in current assets, then the variable cost is a major cost element in cost structure for conducting the operations of these companies.

If variable costs are the major component in the cost structure of these companies, then its means the foundation of this companies are in the field of production operations until its marketing of the product, so it can be concluded that the companies in these sectors have a high level of competition and the potential risk business so that it caused these companies tend to avoid financial risks, including to avoid the debt. If this is indeed case, then this could explain the reason forth negative relationship between debt and fixed asset investment, because these companies will tend to avoid debt and use their own capital including retained earnings to be used in fixed asset investment, as said by Leland and Pyle (1977), where firms with riskier returns will have lower debt levels even when there are no bankruptcy costs. Under existing conditions, it can be said that, the existing debt has been considered the optimum proportion of capital structure. Because if, the company invested in fixed assets by using an existing debt or perform additional debt, then it means profits will be taken to cover the cost of depreciation and interest expense of debt which will lead to further reduction in investment opportunities or make it difficult to finance. This reasons supported by Baker and Wurgler (2002), who said that, firms with substantial growth and investment opportunities have the most to lose when the over-hanging prevents new debt capital from being raised or leads to an in efficient bankruptcy negotiation during the which some investment opportunities are forever lost. On the other hand, the consequences of debt avoidance or useless debt than use their own capital swell as retained earnings, investment in fixed assets of these companies are going to have a low growth rate of the asset as a whole but are likely to have potential benefit, as said by (Myers, 1984; Kale et al., 1991; Sunder and Myers, 1999; Frank and Goyal, 2003).

The tendency of behavior of these companies in obtaining debt or funding from outside sources indicate that the findings in this study support the pecking order theory of Myers (2001), related the factors should be associated with heavy debt financing are capital intensity, high operating leverage and profitability, Nadaraja et al. (2011) with the main point that, highly profitable firms will tend to use internal funding, whereas firms with low profitability tend to use external financing. The results of this study are not consistent with the results of the study by Homaifar et al. (1994), Shah and Khan (2007), except for size and Shamshur (2010), but results of this study is similar with Lim et al. (2012) and consistent with Shubita and Alsawalhah (2012), where we noticed the main point is the higher the debt, the lower the profitability.

\section{CONCLUSION}

In this case, basically companies in Indonesia had similar optimum leverage because they depend on using their internal fund (retained earnings) for making investment in their assets. Furthermore, this findings shows that, sample companies in Indonesia are very carefully obtaining debt as their second funding or these companies will take leverage proportionally after using their internal funding which is retained earnings.

As a whole, the research conclude, that large companies depend their funding from internal, which is make them have more stable cash flow and beside that, the consideration of business risk is very important so 
they keep the capital structure in optimum debt that make them have low probability of bankruptcy. By this findings, it could be said that, companies in Indonesia examined in this study, specially listed in Indonesia Stock Exchange tend to have careful behavior for obtaining debt and have application of pecking order theory.

However, a further study is needed to test the implications of trade off theory and pecking order theory, include to add more variable, because this study have simple model and just limited for period 2009 till 2011. Moreover, the scope of samples for further study need to expand for another sectors, for example finance sector and property sector.

\section{CONTRIBUTION}

We claims three contributions for this study. First, empirical evidence, where, in Indonesia as a developing country, the determinant of capital structures in most of companies is much more determined by business risk, or in the other words, obtained debt is more allocated to cover variable cost derived from current assets, because since investment in fixed asset is not a consideration, then fixed cost in cost structure of this companies are less. This reason explain why in results the tangibility shifting closely in constant, but growth (change percentage in total assets) and size (natural logarithm of total asset) of these companies have tendency to increase.

Second, application of pecking order theory in this period, since business risk is the critical factor and bankruptcy is the main consideration, companies tend to decrease their debt and this result in increasing profitability because of decreasing in debt interest. We refers it as well defined optimal debt ratio, as stated in the pecking order theory by Myers (2001). It is clear now why growth (change percentage in total assets) and size (natural logarithm of total asset) of these companies have tendency to increase, while debt is decrease. If debt is not the main source for funding, then what is the main source for funding? Of course, retained earnings and this is means, debt is companion fund that make these companies are profitable companies although they have high risk of business. By this findings, we could say, the debt philosophy from side of pecking order theory is to survive for sustainability.

Third, as reference for further studies. We give empirical evidence about determinant of capital structure and its impact to profitability from Indonesia as a developing country in the period after shock of global financial crisis in 2008. Also, by this study, we give the relevance theory to explain this phenomenon, but we are not claims pecking order theory is the absolute theory, since we give an evidence that it could be applied in our samples for period 2009 till 2011. We hope this study could be reference by other researchers from other countries in the same area of studies specially for developing countries.

\section{REFERENCES}

Ahmad, Z., N.M.H. Abdullah and S. Roslan, 2012. Capital structure effect on firms performance: focusing on consumers and industrials sectors on Malaysian firms. Int. Rev. Bus. Res., 8: 137-155.

Ahmadinia, H., J. Afrasiabishani and E. Hesami, 2012. A comprehensive review on capital structure theories. Romanian Economic J., 45: 149-164.

Baker, M. and J. Wurgler, 2002. Market timing and capital structure. J. Finance, 57: 1-32. DOI: 10.1111/1540-6261.00414

Bodie, Z., A. Kane, A.J Marcus and P. Mohanty, 2009. Investments. 8th Edn., Tata McGraw-Hill Education, Boston, ISBN-10: 0070151571.

Chen, J.J., 2004. Determinants of capital structure of Chinese-listed companies. J. Bus. Res., 57: 13411351. DOI: 10.1016/S0148-2963(03)00070-5

Cheng, Q., 2005. What determines residual income? Account. Rev., 80: 85-112. DOI: 10.2308/accr.2005.80.1.85

Ching, H.Y., A. Novazzi and F. Gerab, 2011. Relationship between working capital management and profitability in Brazilian listed companies. J. Global Bus. Econom.. 3: 74-86.

Chowdhury, A. and S.P. Chowdhury, 2010. Impact of capital structure on firm's value: Evidence from Bangladesh. Bus. Econ. Horizons, 3: 111-122.

Dittmar, A.K., 2000. Why do firms repurchase stock? J. Bus., 73: 331-355.

Frank, M.Z. and V.K. Goyal, 2003. Testing the pecking order theory of capital structure. J. Financ. Econom., 67: 217-248. DOI: 10.1016/S0304-405X(02)00252-0

Gompers, P.A., 1995. Optimal investment, monitoring and the staging of venture capital. J. Finance, 50: 1461-1489. DOI: $\quad 10.1111 /$ j.15406261.1995.tb05185.x

Hansen, G.S. and B. Wernerfelt, 1989. Determinants of firm performance: The relative importance of economic and organizational factors. Strategic Manage. J., 10: 399-411. DOI: $10.1002 /$ smj.4250100502

Hovakimian, A., T. Opler and S. Titman, 2001. The debt-equity choice. J. Financ. Q. Anal., 36: 1- 24. 
Hovakimian, A., G. Hovakimian and H. Tehranian, 2004. Determinants of target capital structure: The case of dual debt and equity issues. J. Financ. Econom., 71: 517-540. DOI: 10.1016/S0304405X(03)00181-8

Homaifar, G., J. Zietz and O. Benkato, 1994. An empirical model of capital structure: Some new evidence. J. Bus. Finance Account., 21: 1-14. DOI: 10.1111/j.1468-5957.1994.tb00302.x

Hoskisson, R.E., R.A. Johnson and D.D. Moesel, 1994. Corporate divestiture intensity in restructuring firms: Effects of governance, strategy and performance. Acad. Manage. J., 37: 1207-1251. DOI: $10.2307 / 256671$

Hymer, S. and P. Pashigian, 1962. Firm size and rate of growth. J. Political Econ., 70: 556-569.

Kale, J.R., T.H. Noe and G.G. Ramìrez, 1991. The effect of business risk on corporate capital structure: Theory and evidence. J. Finance, 46: 1693-1715. DOI: 10.1111/j.1540-6261.1991.tb04640.x

Khrawish, H.A. and A.H.A. Khraiwesh, 2010. The determinants of the capital structure: Evidence from Jordanian industrial companies. JKAU: Econ. Adm., 24: 173-196. DOI: 10.4197/Eco. 24-1.5

Leland, H.E. and D.H. Pyle, 1977. Informational asymmetries, financial structure and financial intermediation. J. Finance, 32: 371-387. DOI: 10.1111/j.1540-6261.1977.tb03277.x

Lev, B., 1974. On the association between operating leverage and risk. J. Financ. Q. Anal., 9: 627-641.

Lim, T.C., R. Chai, D. Zhao and X.Y. Lim, 2012. Capital structure and political patronage: Evidence from China. Am. J. Bus. Manage., 1: 177-182.

Marsh, P., 1982. The choice between equity and debt: An empirical study. J. Finance, 37: 121-144. DOI: 10.1111/j.1540-6261.1982.tb01099.x

Mohamad, N.E.A.B. and F.N.B. Abdullah, 2012. Reviewing relationship between capital structure and firm's performance in Malaysia. Int. J. Adv. Manage. Econom. 1: 151-156.

Molina, C.A., 2005. Are firms underleveraged? An examination of the effect of leverage on default probabilities. J. Finance, 60: 1427-1459. DOI: 10.1111/j.1540-6261.2005.00766.x
Myers, S.C., 1977. Determinants of corporate borrowing. J. Financ. Econom., 5: 147-175. DOI: 10.1016/0304-405X(77)90015-0

Myers, S.C., 1984. The capital structure puzzle. J. Finance, 39: 575-592. DOI: 10.1111/j.15406261.1984.tb03646.x

Myers, S.C., 2001. Capital structure. J. Econom. Perspectives, 15: 81-102.

Nadaraja, P., A.H. Zulkafli and T.A. Masron, 2011. Family ownership, firm's financial characteristics and capital structure: Evidence from public listed companies in Malaysia. Economia Seria Manage., 14: $141-156$.

Rajan, R.G. and L. Zingales, 1995. What do we know about capital structure? Some evidence from international data. J. Finance, 50: 1421-1460. DOI: 10.1111/j.1540-6261.1995.tb05184.x

San, O.T. and T.B. Heng, 2011. Capital structure and corporate performance of Malaysian construction sector. Int. J. Humanit. Soc. Sci., 1: 28-36.

Shah, A. and S. Khan, 2007. Determinants of capital structure: Evidence from Pakistani panel data. Int. Rev. Bus. Res., 3: 265-282.

Shamshur, A., 2010. Access to capital and capital structure of the firm. Charles University in Prague.

Shubita, M.F. and J.M. Alsawalhah, 2012. The relationship between capital structure and profitability. Int. J. Bus. Soc. Sci.

Sunder, L.S. and S.C. Myers, 1999. Testing static tradeoff against pecking order models of capital structure. J. Financ. Econom., 51: 219-244.

Titman, S. and R. Wessels, 1988. The determinants of capital structure choice. J. Finance, 43: 1-19. DOI: 10.1111/j.1540-6261.1988.tb02585.x

Zhou, X., 2000. CEO pay, firm size and corporate performance: Evidence from Canada. Canad. J. Econom., 33: 213-251. DOI: 10.1111/00084085.00013 